DOI 10.18551/rjoas.2021-11.24

\title{
EVALUATION OF GIANT GOURAMIS (OSPHRONEMUS GOURAMY) GROWTH AND SURVIVAL RATE WITH ADDITIONAL FEEDING FROM KELAKAI LEAVES (STENOCHLAENA PALUSTRIS) SILAGE
}

\author{
Fauzana Noor Arida*, Slamat, Fatmawati, Fitriliyani Indira, Researchers \\ Wati Rahma, Student \\ Study Program of Aquaculture, Faculty of Fisheries and Marine, \\ University of Lambung Mangkurat, Banjarbaru, Indonesia \\ *E-mail: noor.afauzana@ulm.ac.id
}

\begin{abstract}
Giant Gouramis (Osphronemus gouramy) is one type of freshwater fish that has a lot of interest and market demand is quite high. The cultivation of giant guramis is still constrained because of its relatively slow growth. Kelakai (Stenochlaena palustris) is one alternative that can be used as additional feed for giant gouramis because it has a high protein content of $27.31 \%$. The problem with the use of kelakai for fish feed is the high crude fiber content. This nutritional value can be improved through the silage process or fermentation for feed or feed ingredients using microbes (addition of probiotics). Silage comes from forage or agricultural waste that is preserved in a fresh state through a fermentation process in a container.The study aimed to evaluate the growth and survival rate of giant gouramis. This study used a Complete Random Design with 4 Treatments with 3 repetitionsconsisting of Treatment 1 (K0): Pellet + fresh kelakai leaves: Treatment 2 (K1): Pellet + Kelakai leaves Silage for1 day incubation; Treatment 3 (K2): Pellet + Kelakai leaves Silage for 2 days incubation; Treatment 4 (K3): Pellet + Kelakai leaves Silage for3 days incubation. The results showed that the relative weight growth rate ranged from $21.13-25.16 \%$, the relative length growth of the body ranged from $1.5-1.57 \%$, survival ranged from $72-82 \%$ and the feed conversion rate ranged from 1.5-1.69.
\end{abstract}

\section{KEY WORDS}

Silage, kelakai leaf, additional feed, giant gouramis, growth, survival rate.

Giant gouramis (Osphronemus gouramy) is one type of freshwater consumption fish that has many enthusiasts and is one of the fishery commodities with a fairly high market demand (Pratama, Susilawati and Yuniarti, 2018). Giant gouramis has a high and stable economic value, thereby increasing the competitiveness of aquaculture commodities.

The development of Giant gouramis cultivation is still constrained because its growth is still relatively slow, both in the phase of fry maintenance and enlargement (Sitanggang and Sarwono, 2001). One of the reasons for the slow growth rate of gouramy is that gouramy is classified as herbivore so that the physiological condition of the digestive tract is longer than its body length (Nasir, 2002). The long digestive tract of Giant gouramis causes the process of absorption and digestion of food to take a relatively long time (Yandes, Affandi and Mokoginta, 2003).

Several studies on Giant gouramis feed have been carried out using several plants such as cassava leaves, sente leaves and water hyacinth leaves, lamtoro leaves, kale leaves, spinach leaves, and papaya leaves, either given directly, as a mixture in artificial feed formulations, or as an additive. supplementary feed which is given in combination with artificial feed.

Kelakai (Stenochlaena palustris) is an alternative that can be used as additional feed for Giant gouramis. The results of the research by Fatmawati and Fauzana (2016), stated that the young shoots of the young leaves of Kelakai contained $27.31 \%$ protein compared to the old leaves of $26.79 \%$. The constraint on the use of kalakai for fish feed is the high crude fiber content of $10.45 \%$ for young leaves and $15.62 \%$ for old leaves (Fatmawati and Fauzana, 2016), while fish needs for crude fiber are not more than 8\% (Mujiman, 2000). 
This improvement in nutritional value can be improved through the silage process or fermentation of feed or feed ingredients using microbes (addition of probiotics) (Arief, Fitriani and Surbekti, 2014). Silage comes from vines or agricultural waste that is preserved in a fresh state through a fermentation process in a container (Yuliati et al, 2018).Improvements in nutritional value can be improved through the silage process or fermentation of feed or feed ingredients using microbes (Arief, Fitriana and Subekti, 2014).

The use of kelakai leaves has been widely used for human food, but as raw material for fish feed has not been widely used, so that information on the use of kelakai leaves in fish feed is still limited. A study on the provision of kelakai leaf silage for gouramy as additional feed is needed to determine its effect on the growth and survival of giant gouramis.

\section{MATERIALS AND METHODS OF RESEARCH}

This research was conducted from May to September 2021at the Wet Laboratory of the Faculty of Fisheries and Marine, ULM Banjarbaru. The tools and materials used were happa, plastic clips, rope, galam wood, ring wood, digital scales, digital calipers, blowers, aerator stones, hoses, giant gouramis fry, silage of kelakai leaves and pellets.

a. Preparation of Happa and Fish Fry. The research used 12 pieces of black happa measuring $1 \mathrm{~m} \times 1 \mathrm{~m} \times 1 \mathrm{~m}$ which were installed hanging on the pond and equipped with a wooden frame and aeration. The fish fry used in this study were giant gouramis fry measuring between 3 and $4 \mathrm{~cm}$ which came from Bincau KarangIntan Cultivators. Each happa was stocked with 30 giant gouramis fry.

b. Feed Preparation. The main feed was PF pellets with nutrients; protein $41 \%$, fat $6 \%$, fiber $2.5 \%$, water content $11 \%$ and ash content $16 \%$. Additional feed was silage of kalakai leaves which are stored in plastic for 1, 2 and 3 days according to treatment, as follows:

- Kelakai leaves as much as 100 grams, washed and drained;

- Kelakai leaves are weighed and cut into small pieces;

- Kelakai leaves are put in plastic and add 5\% molasses and stir until evenly, then the plastic is given holes by means of cut short in some places;

- Kelakai leaves are stored from 1 to 3 days.

c. Feeding Management. The giant gouramis fry culture was carried out for 60 days. Feed given is PF pellets with a frequency of twice a day as much as $4 \%$ of the biomass at $08.00 \mathrm{am}$ and $05.00 \mathrm{pm}$. Kalakai leaves silage was given once a day as much as $2 \%$ of the biomass at $05.00 \mathrm{pm}$. Sampling was carried out every 15 days during the cultivation of giant gouramis.

This research was carried out an experimental method using a completely randomized design (CRD) with 4 treatments and 3 repetitions. The treatment in this study is as follows:Treatment 1 (K0): Pellet + fresh kelakai leaves: Treatment 2 (K1): Pellet + Kelakai leaves Silage for 1 day incubation; Treatment 3 (K2): Pellet + Kelakai leaves Silage for 2 days incubation; Treatment 4 (K3): Pellet + Kelakai leaves Silage for 3 days incubation.

Parameters:

a. Relative Weight Growth. Relative weight growth is defined as the percentage of weight growth at any given time interval formulated by Effendie (2002), namely:

$$
W=\frac{W t-W o}{W o} \times 100 \%
$$

b. Relative Length Growth. The relative length growth can be calculated using the Effendie (2002) formula as follows:

$$
L=\frac{L t-L o}{L o} \times 100 \%
$$

c. Survival Rate. According to Efendie (2002) survival rate of fish as follows:

$$
\mathrm{SR}=\mathrm{Nt} / \mathrm{No} \times 100 \%
$$


d. The feed conversion ratio (FCR) is the ratio of amount of feed given ti produce one kilogram of fish biomass. FCR is calculated using formula of Parker (2012) as follows:

$$
F C R=F /(D+W t)-W_{0}
$$

e. Water Quality. The water quality parameters observed were temperature, $\mathrm{pH}$, dissolved oxygen (DO) and ammoniaat the Laboratory of Water Quality and HydroBioecology, Faculty of Fisheries and Marine ULM Banjarbaru. Water quality parameters were measured at the beginning, the middle and the end of cultivation.

d. Data analysis. Data analysis was carried out on relative growth, survival, and feed conversion ratio, with Analysis of variance(Hanafiah, 1993).

\section{RESULTS AND DISCUSSION}

Table 1 showed that the average relative weight growth of giant gouramis was between $21,13 \pm 2,21-25,16 \pm 2.35 \%$. The highest average relative weight growth was found in $\mathrm{K} 1$ treatment $(25.16 \%)$ and the lowest was found in K0 treatment $(21.13 \%)$. The results of relative weight growth in this study were higher than the research of Nofyan (2005), thataverage relative weight growth were $0,13 \%$ on culture of giant gouramis used pellets with water hyacinth flour, or with sente leaves flour were $0.28 \%$. Similarly, when compared with the results of the study by Sepni, Efrizal, and Rahayu (2015)showed relative weight growth of giant gouramis just from $0,28 \pm 0,01 \%$ untill $0.31 \pm 0.02 \%$ with feed of taro leaves flour.Analysis of variance (ANOVA) had no significant effect on the relative weightgrowth of giant gouramis even though the protein content of the silage of kelakai leaves increased. As herbivorous fish, giant gouramis have the ability to utilize carbohydrates better than protein, so giant gouramis utilize energy for growth by digesting more carbohydrates than protein.

Table 1 - Average of Relative Weight Growth (\%)

\begin{tabular}{lllll}
\hline \multirow{2}{*}{ Repetitions } & Treatments & & & \\
\cline { 2 - 5 } & K0 & K1 & K2 & K3 \\
\hline 1 & 22,59 & 24 & 26,65 & 19,83 \\
2 & 18,59 & 23,62 & 24,96 & 25,39 \\
3 & 22,21 & 27,87 & 19,14 & 23,59 \\
\hline Total & 63.39 & 75.50 & 70.76 & 68.82 \\
\hline Average & $21,13 \pm 2,21^{\mathrm{a}}$ & $25,16 \pm 2.35^{\mathrm{a}}$ & $23,58 \pm 3.95^{\mathrm{a}}$ & $22,94 \pm 2.84^{\mathrm{a}}$ \\
\hline
\end{tabular}

Table 2 - Average of Relative Length Growth (\%)

\begin{tabular}{|c|c|c|c|c|}
\hline \multirow[b]{2}{*}{ Repetitions } & \multicolumn{4}{|l|}{ Treatments } \\
\hline & KO & K1 & K2 & K3 \\
\hline 1 & 1,64 & 1,43 & 1,53 & 1,73 \\
\hline 2 & 1,47 & 1,30 & 1,61 & 1,43 \\
\hline 3 & 1,61 & 1,77 & 1,43 & 1,42 \\
\hline Total & 4.72 & 4.50 & 4.57 & 4.58 \\
\hline Average & $1,57 \pm 0.09^{a}$ & $1,50 \pm 0.24^{\mathrm{a}}$ & $1,52 \pm 0.09^{a}$ & $1,53 \pm 0.18^{a}$ \\
\hline
\end{tabular}

Table 2 showed that the average relative length growth of giant gouramis was between $1,50 \pm 0.24-1,57 \pm 0.09 \%$. The results of the relative length growth of giant gouramis in this study were higher than the research results of Elfrida and Yuspita (2017) where during cultivation for 30 days with taro leaves feeding, average relative length growth of giant gouramis were $0.78 \%$, and lower than Vega's study ( 2017) by gouramy fry feeding using agati leaves flour with an average of $3.40 \%$.

Table 3 - Survival Rate of Giant Gouramis Fry (\%)

\begin{tabular}{|c|c|c|c|c|}
\hline \multirow{2}{*}{ Repetitions } & \multicolumn{4}{|l|}{ Treatments } \\
\hline & $\mathrm{KO}$ & $\mathrm{K} 1$ & $\mathrm{~K} 2$ & K3 \\
\hline 1 & 93,33 & 66,66 & 76,66 & 93,33 \\
\hline 2 & 36,66 & 93,33 & 93,33 & 86,66 \\
\hline 3 & 86,66 & 56,66 & 70 & 66,66 \\
\hline Total & 216.65 & 216.65 & 239.99 & 246.65 \\
\hline Average & $72.22 \pm 13.88^{a}$ & $72.22 \pm 18.95^{\mathrm{a}}$ & $80 \pm 12.01^{a}$ & $82.22 \pm 13.88^{a}$ \\
\hline
\end{tabular}


The survival rate of giant gouramy fry reared for 60 days with additional feeding of kelakai leaves silage resulted in a high survival rate from $72.22 \pm 13.88 \%-82.22 \pm 13.88 \%$. The survival rate in trearment $\mathrm{KO}$ and $\mathrm{K} 1(72,22 \%)$ lower than the provisions of SNI (2000), but in treatment $\mathrm{K} 2(80 \%)$ and $\mathrm{K} 3(82,22 \%)$ higher than the provisions of SNI (2000) which is $80 \%$. This survival rate in this study is lower than the study of Syaputra, Santoso and Taslim (2018) with additional feeding with gamal leaves flour which is $95.45 \%$, but K2 (80\%) and K3 $(82 \%)$ treatments was higher compared to the provisions of SNI (2000). The good and optimal water qualityvalue causes giant gouramy fry to live well.

Table 4 - Average of FCR

\begin{tabular}{|c|c|c|c|c|}
\hline \multirow{2}{*}{ Repetitions } & \multicolumn{4}{|l|}{ Treatments } \\
\hline & K0 & K1 & $\mathrm{K} 2$ & K3 \\
\hline 1 & 1,7 & 1,61 & 1,66 & 1,78 \\
\hline 2 & 1,37 & 1,45 & 1,57 & 1,71 \\
\hline 3 & 1,68 & 1,43 & 1,69 & 1,57 \\
\hline Total & 4.75 & 4.49 & 4.92 & 5.06 \\
\hline Average & $1,58 \pm 0.18^{a}$ & $1,50 \pm 0.08^{a}$ & $1,64 \pm 0.06^{a}$ & $1,69 \pm 0.11^{a}$ \\
\hline
\end{tabular}

Table 5 - The Value of Water Quality

\begin{tabular}{lllll}
\hline Parameter & & & & \\
\hline Treatment & Temperature $\left(^{0}\right)$ & $\mathrm{pH}$ & $\mathrm{DO}(\mathrm{mg} / \mathrm{L})$ & Amoniak $(\mathrm{mg} / \mathrm{L})$ \\
\hline K0 & 27 & 6,6 & 2,85 & 0,12 \\
K1 & 27 & 6,6 & 3,14 & 0,13 \\
K2 & 27 & 6,6 & 2,83 & 0,13 \\
K3 & 27 & 6,6 & 2,88 & 0,13 \\
\hline
\end{tabular}

Table 4 showed that the average FCR was between $1,50 \pm 0.08$ until $1,69 \pm 0.11$. Feed conversion ratios (FCR) are calculated to determine the cost and efficiency of feeding the fish. FCR for fish can vary from less than 1,5 to as high as 4 to more (Parker, 2012). The value of the feed conversion ratio in this study is better than the study of Vega (2017) by feeding using turi leaves flour for gouramy which is 2.56 and result study by Anti, Santoso and Utomo (2018) which is $2.35 \pm 0,13$. The results of water quality on culture of giant gouramis fry were in the range that supported the growth and survival of giant gouramis fry, that fish can grow well in a temperature range of $24-28^{\circ} \mathrm{C}, \mathrm{pH} 6,5-8,5, \mathrm{DO} 4-7 \mathrm{mg} / \mathrm{L}$, and ammonia $\leq$ 0,016 mg/L (Kordi, 2013).

\section{CONCLUSION}

The Fresh Kelakai leaves and Silage of kelakai leaves with 1-3 days incubation can be used as additional feed for giant gouramis fry, with relative weight growth rate ranged from $21,13 \pm 2,21-25,16 \pm 2.35 \%$, relative length growth from $1,50 \pm 0.24-1,57 \pm 0.09 \%$, survival rate from $72.22 \pm 13.88 \%-82.22 \pm 13.88 \%$ and feed conversion ratio $1,50 \pm 0.08-1,69 \pm 0.11$. The water quality on culture of giant gouramis fry were in the range to supported the growth and survival of giant gouramis fry.

\section{ACKNOWLEDGMENTS}

This work was partially supported by the Rector and head of the Institute for Research and Community Service, University of Lambung Mangkurat, for providing PNBP research funds through the Compulsory Research Lecturer Program with DIPA funding of 2021 (No. 023.17.2.677518/2021: November 23, 2020, Decree of the Rector of University of Lambung Mangkurat No. 697/UN8/PG/2021: March 22, 2021).

\section{REFERENCES}

1. Anti,U.T., L.Santoso and D.S.C Utomo. 2018. The Effect Of Moringa Leaves (Moringa oleifera) Flour Suplementation On Feed To Growth Performance of Gouramy Fish (Oshpronemus gouramy). Jurnal Sains Teknologi Akuakultur, 2(2): 22-31. 
2. Arief, M., N., Fitrianiand S., Subekti. 2014. The Effect of Different Probiotics on Commercial Feeds on Growth and Feed Efficiency of Sangkuriang Catfish (Clarias sp.) Jurnalllmiah Perikanan dan Kelautan. 6(1): 49-52. 6(1): 49-52.

3. Effendi MI. 2002. Fisheries Biology, Section. I. Study Natural History. Faculty of Fisheries, Bogor Agricultural University.

4. Elfrida and Yuspita, Y. 2017. Effect of feeding taro leaves on the growth of gouramy (Osphronemus gouramy) in Sungai Liput Village, Aceh Tamiang Regency. Jurnal Jeumpa. 4(2).

5. Fatmawatiand N.A. Fauzana. 2016. Production of Climbing perch (Anabas testudineus Bloch) Feed Based on Local Potential Wetlands of Kalakai Flour (Stennochlaenapalutris). PNBP Research Report. ULM. Banjarmasin.

6. Hanafiah, Kemas Ali. 1993. Experimental Design, Theory and Application. Rajawali. Jakarta.

7. Kordi, M. Ghufran H, 2013. The Cultivation of Fish Consumption in Fresh Water. Lily Publisher. Yogyakarta.

8. Mudjiman A. 2000. Fish Feed. PT.Penebar Swadaya. Jakarta.

9. Nasir. M. 2002. Effect of Different Cellulose Levels in Feed for Intestinal Length and Digestive Enzyme Activity of Gouramy Fry (Osphronemus gouramy). Tesis. IPB. Bogor.

10. Nofyan, E. 2005. Effect of Feeding from Vegetable and Animal Sources for Various Physiological Aspects of Gouramy (Osphronemus gouramy). Indonesian Journal of Ichtylogy. 5(1).

11. Parker, R., 2012. Aquaculture Science. Third Edition. Delmar Cengage Learning. USA.

12. Pratama, B. A., Susilowati, T. and Yuniarti, T. 2018. Effect of Temperature Differences for Egg Hatching Time, Hatchability, Survival rate, and Growth of Starin Bastar Gouramy (Osphronemus gouramy). Juornal of Tropical Aquaculture Science 2(1): 59-65.

13. Sepni, Efrizal and R.Rahayu., 2019. Utilization the Combination of Taro (Colocasia Esculenta L. Schott) Leaves Flour and Soybean Flour in Artificial Feed on the Growth Weight of Giant Gouramis Fish (Osphronemus Gourami L.). Metamorfosa, Journal of Biological Science 6 (1): 44-50.

14. Sitanggang, M. and B., Sarwono. 2001. Culture of Gouramy. Penebar Swadaya. Jakarta.

15. SNI, 2000. Production of Gouramy (Osphronemus gouramy) Fry. Spread Fry Class. National Standardization. Jakarta.

16. Syaputra, R., Santoso, L., and Tarsim. 2018. Effect of Addition of Gamal Leaves Flour (Gliricidia sepium) to Artificial Feed for Survival and Growth of Giant Gouramis (Osphronemus gouramy). Journal of Aquaculture Technology Science. 2(1):1-11.

17. Vega, Y.T.D, 2017. The Use of Turi Leaves Flour (Sesbania Grandiflora) In Artificial Feed To Increase Growth And Survival Of Giant Gouramis (Osphronemus Gouramy). Faculty of Fisheries and Marine Sciences, University of Muhammadiyah Pontianak.

18. Yandes, Z., Affandiand Mokoginto, I. 2003. Effect of Cellulose in Feed for Biological Conditions of Giant Gouramis Fry (Osphronemus gouramy). Indonesian Journal of Ichtiology. 3(1): 27-33.

19. Yuliati, Yati B., Solihudin, Saadah D. Ranchman, Syafri Ismayadi, Rustaman, Darwatidan and Atiek R. Noviyanti. 2018. Making Silage from Napier Grass for Animal Feed in Pasawahan Village, Tarogong Kaler District, Garut Regency. Department of Chemistry FMIPA Padjadjaran University, Bandung. 